Демидова П. I.

\title{
ВІДДАЛЕНІ РЕЗУЛЬТАТИ ЛІКУВАННЯ ГІПЕРЕСТЕЗІЇ ЗУБІВ ІЗ ВИКОРИСТАННЯМ НИЗЬКОІНТЕНСИВНОГО ЛАЗЕРНОГО ВИПРОМІНЮВАННЯ ТА АПІПРОДУКТІВ
}

\author{
Харківський національний медичний університет, Україна
}

polinademidovva@gmail.com

Гіперестезія зубів часто виникає у пацієнтів за умов наявності в них захворювань пародонту, а саме різних ступенів важкості генералізованого пародонтиту. Хоча на сьогодні існує велике різноманіття методів лікування гіперестезії зубів, на жаль, досі $€$ необхідність для оптимізації існуючих методів лікування заради отримання пролонгованих результатів у зниженні показників гіперестезії зубів.

Метою цього дослідження було оцінити ефективність лікування гіперестезії зубів у хворих на генералізований пародонтит хронічного перебігу запропонованим методом лікування із використанням низькоінтенсивного лазерного випромінювання та апіпродуктів.

У дослідженні прийняло учать 104 хворих із генералізованим пародонтитом хронічного перебігу та гіперчутливістю зубів. Пацієнти були поділені на 4 групи відповідно до отриманого методу лікування. Для оцінки ступеня вираженості гіперестезії зубів використовували індекси інтенсивності та розповсюдженості гіперестезії зубів. В першій групі для лікування гіперестезії зубів використовували лак на основі фториду натрію, у другій - настойку прополісу, в третій - низькоінтенсивне лазерне випромінювання(довжина хвилі 810 нм). У четвертій групі лікування проводилося за допомогою комбінованого використання настойки прополісу та низькоінтенсивного лазерного випромінювання (довжина хвилі 810 нм). Значення отриманих індексів інтенсивності та розповсюдженості гіперестезії зубів оцінювали до лікування, одразу після лікування, через тиждень, 1 місяць, 3 місяці, пів року та рік після лікування у кожній групі. Статистичну значущість результатів оцінювали у IBM SPSS Statistics, V. 25.0(Armonk, NY: IBM Corp.).

Середні значення показників індексів інтенсивності та розповсюдженості гіперестезії зубів суттєво не відрізнялися до лікування у всіх чотирьох групах. В кожній групі лікування було ефрективним одразу після його отримання, про що свідчить значне зниження значень індексів. Середні значен- ня індексів інтенсивності та розповсюдженості гіперестезії зубів не повернулися до значень отриманих до лікування у всіх чотирьох групах, проте найнижчі значення були отримані у четвертій групі. Результати порівняння між групами є статично значущими ( $p<0,05)$.

Аналіз отриманих результатів індексів оцінки ефективності запропонованого методу лікування гіперестезії зубів свідчить про високу клінічну стійкість отриманого ефекту та його пролонговану дію.

Ключові слова: гіперестезія зубів, пародонтит, прополіс, діодний лазер.

Зв'язок роботи 3 науковими програмами, планами, темами. Наукова робота проведена у рамках НДР Харківського національного медичного університету МОЗ України «Характер, структура та лікування основних стоматологічних захворювань», № держ. реєстрації $0116 \mathrm{U} 004975$.

Вступ. За даним літератури гіперестезія зубів (ГЗ) є поширеним явищем і зустрічається у 3\%57\% населення, найчастіше відзначається у людей віком між 30-40 років. Відомо, що чоловіки в порівняні з жінками страждають на ГЗ рідше. Поняття ГЗ описується як «короткий, різкий біль, що виникає за рахунок оголення дентину зубів у відповідь на подразники, як правило, термічні, тактильні, осмотичні чи хімічні" [1, 2].

Часто виникнення гіперестезії зубів пов'язане з генералізованим пародонтитом та наслідками його лікування [3]. Механізм болю при ГЗ пояснюється кількома теоріями. Найбільш широко прийнята гідродинамічна теорія. Теорія базується на тому, що за рахунок теплових, тактильних чи хімічних подразників змінюється рух рідини в дентинних канальцях, що в свою чергу провокує деформацію нервових закінчень в пульпі, в результаті чого виникає відповідь у вигляді болю [1, 4].

Існуючі на сьогодні методи лікування ГЗ ґрунтуються на зменшенні руху рідини в дентинних канальцях, що базується на гідродинамічній теорії. За даними публікацій останніх років, досі не існує 
цілком ефрективного лікування ГЗ [4]. Прополіс, відомий як бджолиний клей, - це природна смолиста речовина, що збирається бджолами з рослин. Найчастіше прополіс містить суміші смол, ефірних олій, воску, амінокислот, мінеральних речовин, етанолу, комплексу вітамінів A, E, В та біофлавоноїдів, з чим і пов'язана біологічна активність прополісу. Прополіс широко застосовується не тільки в медицині, але і в сучасній стоматології через його протизапальну, антиоксидантну, антибактеріальну, противірусну та протигрибкову дії [5, 6]. Прополіс широко використовують для лікування ГЗ $[6,7,8]$.

Було опубліковано ряд статей, присвячених використанню лікування ГЗ за допомогою різних типів лазерів. Так, популярності набуло використання низькоінтенсивного лазерного випромінювання (НІЛВ). В останніх дослідженнях НІЛВ було запропоновано як ефективне лікування ГЗ, за рахунок підвищення метаболічної активності клітин пульпи, що сприяє виробленню третинного дентинy $[9,10]$.

В останні роки найпоширенішим компонентом десенситайзерів $€$ фрторид натрію. Механізм дії пояснюється закупорюванням дентинних канальців кристалами фториду кальцію. Облітерація дентинних канальців кристалами фрториду кальцію зменшує рух рідини, що допомагає зменшити рівень болю [1, 3].

Метою цього дослідження було порівняння ефрективності застосування лаку на основі фрториду натрію, настойки прополісу, низькоінтенсивного лазерного випромінення з довжиною хвилі 810 нм та комбінованого застосування настойки прополісу з НІЛВ для зменшення ознак гіперестезії зубів у хворих на генералізований пародонтит хронічного перебігу при тривалому спостереженні.

Матеріал та методи дослідження. У досліджені, яке проводилося на кафедрі терапевтичної стоматології Харківського національного медичного університету на базі університетського стоматологічного центру Харківського національного медичного університету, прийняло участь 104 хворих із генералізованим пародонтитом хронічного перебігу різного ступеню важкості та підвищеною чутливістю зубів. Із них було 63 жінки та 41 чоловіків з се-

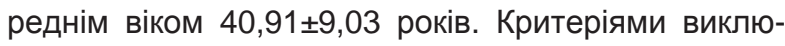
чення з дослідження вважали наявність онкологічних захворювань, вагітності, алергічні реакції на апіпродукти. Для характеристики ступеня вираженості ГЗ та її генералізації використовували індекси інтенсивності ГЗ (ІІГЗ) та розповсюдженості ГЗ (ІРГЗ), запропоновані I . Б. ІІІторіною.

Для визначення ступеня вираженості ГЗ проводили перевірку чутливості кожною зуба на дію різноманітних подразників. Спочатку визначали реак- цію зуба на термічні, потім на хімічні і, в останню чергу, на механічні (тактильні) подразники.

Після визначення чутливості хворі, що брали участь у нашому досліджені, були поділені на 4 групи залежно від отриманого лікування. Пацієнти розподілялися по групах рандомно. В першій групі проводилося лікування ГЗ за допомогою «Ftorplen» (Latus, Україна), що містить препарат фрториду натрію і фрториду кальцію. За допомогою аплікатора, що йде в комплекті, лак наносився на висушену поверхню зуба. Лак наносився тричі через день.

У другій групі проводили лікування за допомогою настойки прополісу (ТОВ «Тернофарм», Україна, Тернопіль). Чутливі зуби, були ізольовані за допомогою ватних валиків, після чого проводилося нанесення рідкого кофердаму (OpalDam, Ultradent, USA), для запобігання попадання лікарського засобу на ясенний край. Настойка прополісу наносилася за допомогою полірувальної головки та мікромотору протягом 60 секунд, після цього зуб залишали на 5 хвилин. Процедуру проводили тричі з інтервалом у 48 годин.

У третій групі проводили лікування ГЗ із використанням низькоінтенсивного лазерного випромінювання. Для цього було використано лазерний терапевтичний апарат «Лика-Терапевт М» (ЧМПП «Фотоніка Плюс», м. Черкаси) та виносна рукоятка ВРИП1, яка працює в інфрачервоному оптичному діапазоні з довжиною хвилі 810 нм та максимальною потужністю 100 мВт. Процедуру корекції ГЗ проводили протягом 3 хвилин в постійному режимі. Насадка була встановлена перпендикулярно до поверхні причинного зуба у приясенній ділянці. Випромінення проводили в трьох різних точках, у кожній точці по 1 хвилині. Процедуру було проведено тричі з інтервалом у 48 годин.

У четвертій групі лікування проводилося за допомогою комбінованого використання настойки прополісу та низькоінтенсивного лазерного випромінювання. Чутливі зуби були ізольовані за допомогою ватних валиків, після чого проводилося нанесення рідкого кофрердаму (OpalDam, Ultradent, USA). Настойка прополісу наносилася за допомогою полірувальної головки та мікромотору протягом наступних 60 секунд. Потім проводили низькоінтенсивне лазерне випромінювання протягом 3 хвилин в постійному режимі. Насадка була встановлена перпендикулярно до поверхні причинного зуба у приясенній ділянці. Випромінення проводили в трьох різних точках, у кожній точці по 1 хвилині. Лікування проводилося тричі з інтервалом у 48 годин.

Усім пацієнтам були дані рекомендації не вживати їжі та напоїв наступні дві години після проведених процедур. Впродовж усього терміну 
дослідження не застосовувати ніяких засобів, що впливають на чутливість зубів.

Дослідження виконані з дотриманням основних положень «Правил етичних принципів проведення наукових медичних досліджень за участю людини», затверджених Гельсінською декларацією (1964-2013 рр.), ICH GCP (1996р.), Директиви ЄEC № 609 (від 24.11.1986р.), наказів МОЗ України № 690 від 23.09.2009 р., № 944 від 14.12.2009 р., № 616 від 03.08.2012 р. Кожен пацієнт підписував інформовану згоду на участь у дослідженні, і вжиті всі заходи для забезпечення анонімності пацієнтів.

Результати лікування гіперестезії твердих тканин зубів оцінювали по динаміці змін показників ІРГЗ та ІІГЗ, до лікування, одразу, 1 тиждень, 1 місяць, 3 місяці, 6 місяців, 1 рік після лікування. Всі отримані дані статистично вивчалися за допомогою IBM SPSS Statistics, V. 25.0 (Armonk, NY: IBM Corp.).

Результати дослідження. Середні значення разом із стандартним відхиленням вивчаємих індексів гіперестезії зубів, а саме ІРГЗ та ІІГЗ зубів можна побачити в таблиці 1 та 2. Виходячи з отрима- них даних та проведеного міжгрупового статистичного порівняння можна сказати, що середні значення обох показників суттєво не відрізнялися в усіх чотирьох групах до лікування. Так, ІРГЗ в чотирьох

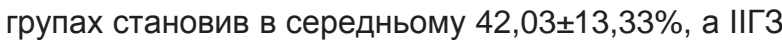
$1,97 \pm 0,41$ балів. Миттєвий ефект після лікування спостерігався в усіх групах, про що каже значне зниження ІІГЗ та ІРГЗ. Так у першій групі середнє значення IPГЗ стало меншим на $32 \%$, в другій групі на $30,15 \%$, у третій групі - на 31,77\% та у четвертій групі - на 33,11 \%. У першій групі значення ІІГЗ зменшилося на 1,24 бали, в другій - на 1,14 бали, в третій групі - на 1,22 бали та в четвертій на 1,32 бали. Порівняння показників ІРГЗ між усіма групами були статистично значущі $(p<0,05)$, проте як для ІІГЗ значущими було порівняння лише між результатами другої та четвертої групи $(p<0,05)$.

Починаючи з першого тижня середні значення обох індексів почали збільшуватись в трьох останніх групах, на той час коли в першій групі лікування індекси продовжували зменшуватися порівняно 3 отриманими показниками одразу після лікування (табл. 1, 2).

Таблиця 1 - Зміни індексу розповсюдженості ГЗ (\%)

\begin{tabular}{l|c|c|c|c|c|c|c}
\hline & До лікування & $\begin{array}{c}\text { Одразу після } \\
\text { курсу } \\
\text { лікування }\end{array}$ & $\begin{array}{c}\text { Через } \\
\text { 1 тиждень }\end{array}$ & $\begin{array}{c}\text { Через } \\
\text { 1 місяць }\end{array}$ & $\begin{array}{c}\text { Через } \\
\text { 3 місяці }\end{array}$ & $\begin{array}{c}\text { Через } \\
\text { м місяців }\end{array}$ & $\begin{array}{c}\text { Через } \\
\mathbf{1} \text { рік }\end{array}$ \\
\hline Група 1 & $41,92 \pm 13,73$ & $9,92 \pm 0,80^{*}$ & $9,12 \pm 0,59^{*}$ & $12,85 \pm 0,68^{*}$ & $17,69 \pm 0,88^{*}$ & $22,12 \pm 1,03^{*}$ & $25,38 \pm 1,33^{*}$ \\
\hline Група 2 & $41,69 \pm 13,54$ & $11,54 \pm 0,65^{*}$ & $13,19 \pm 0,69^{*}$ & $17,42 \pm 0,81^{*}$ & $20,81 \pm 1,02^{*}$ & $23,12 \pm 1,07^{*}$ & $26,08 \pm 1,29^{*}$ \\
\hline Група 3 & $42,12 \pm 13,88$ & $10,35 \pm 0,70^{*}$ & $11,54 \pm 0,76^{*}$ & $13,58 \pm 0,90^{*}$ & $14,35 \pm 0,94^{*}$ & $15,12 \pm 0,99^{*}$ & $17,69 \pm 1,05^{*}$ \\
\hline Група 4 & $42,38 \pm 12,91$ & $9,27 \pm 0,67^{*}$ & $10,23 \pm 0,71^{*}$ & $11,73 \pm 0,78^{*}$ & $10,42 \pm 0,76^{*}$ & $8,73 \pm 0,60^{*}$ & $9,04 \pm 0,72^{*}$ \\
\hline
\end{tabular}

Примітка: *дані статистично достовірні порівняно з показниками до лікування $(p<0,05)$.

Таблиця 2 - Зміни індексу інтенсивності ГЗ (бали)

\begin{tabular}{l|c|c|c|c|c|c|c}
\hline & $\begin{array}{c}\text { До } \\
\text { лікування }\end{array}$ & $\begin{array}{c}\text { Одразу після } \\
\text { курсу ліку- } \\
\text { вання }\end{array}$ & $\begin{array}{c}\text { Через } \\
\text { 1 тиждень }\end{array}$ & $\begin{array}{c}\text { Через } \\
\mathbf{1} \text { місяць }\end{array}$ & $\begin{array}{c}\text { Через } \\
\text { 3 місяці }\end{array}$ & $\begin{array}{c}\text { Через } \\
\mathbf{6} \text { місяців }\end{array}$ & $\begin{array}{c}\text { Через } \\
\mathbf{1} \text { рік }\end{array}$ \\
\hline Група 1 & $1,97 \pm 0,40$ & $0,73 \pm 0,25^{*}$ & $0,66 \pm 0,24^{*}$ & $0,94 \pm 0,29^{*}$ & $1,37 \pm 0,28^{*}$ & $1,62 \pm 0,36^{*}$ & $1,71 \pm 0,41^{*}$ \\
\hline Група 2 & $1,98 \pm 0,43$ & $0,84 \pm 0,29^{*}$ & $0,96 \pm 0,34^{*}$ & $1,28 \pm 0,22^{*}$ & $1,60 \pm 0,21^{*}$ & $1,69 \pm 0,28^{*}$ & $1,77 \pm 0,29^{*}$ \\
\hline Група 3 & $1,97 \pm 0,41$ & $0,75 \pm 0,24^{*}$ & $0,84 \pm 0,23^{*}$ & $0,95 \pm 0,24^{*}$ & $1,08 \pm 0,26^{*}$ & $1,15 \pm 0,32^{*}$ & $1,27 \pm 0,39^{*}$ \\
\hline Група 4 & $1,96 \pm 0,41$ & $0,67 \pm 0,21^{*}$ & $0,75 \pm 0,21^{*}$ & $0,87 \pm 0,19^{*}$ & $0,80 \pm 0,21^{*}$ & $0,64 \pm 0,12^{*}$ & $0,70 \pm 0,13^{*}$ \\
\hline
\end{tabular}

Примітка:夫 дані статистично достовірні порівняно з показниками до лікування $(p<0,05)$.

Так, ІРГЗ в першій групі зменшився ще на 0,8 \%, а ІІГЗ на 0,07 бали. Цікаво, що вже після першого місяця та продовжуючи до 1 року показники збільшувались у перших трьох групах, коли показники четвертої групи впродовж цього терміну постійно знижувалися (рис. 1, 2). Найбільш важливим для оцінки лікування гіперестезії зубів $є$ тривалість отриманого ефекту після лікування, тому велика увага приділялася оцінці показників індексів ГЗ через один рік після лікування. Порівняно зі значеннями отриманими до лікування значення обох показників у всіх чотирьох групах значення ІІГЗ та IPГЗ були значно менші. Так у першій групі ІРГЗ

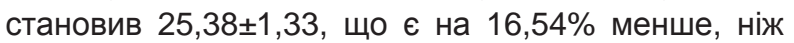

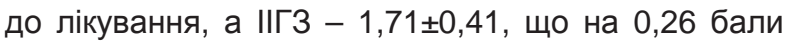
менше, аніж до лікування. У другій групі IPГЗ через рік був на 15,88\% менше, ніж до лікування, ІІГЗ зменшився на 0,22 бали. У третій групи через рік ІРГЗ зменшився на 24,43\%, а ІІГЗ - на 0,7 бали. Тоді як у четвертій групі середнє значення ІРГЗ було аж на 33,34\% менше, а ІІГЗ був менший на 1,26 бали. Порівняння показників ІРГЗ через рік 


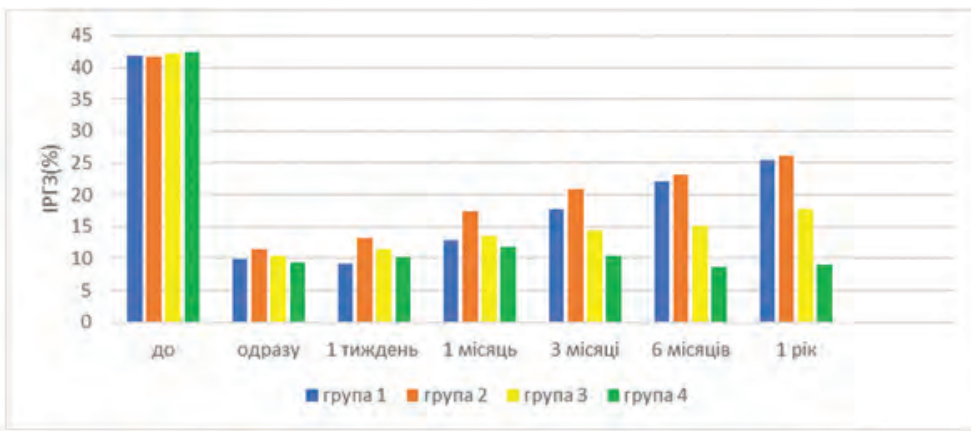

Рис. 1. Показники IPГЗ протягом року

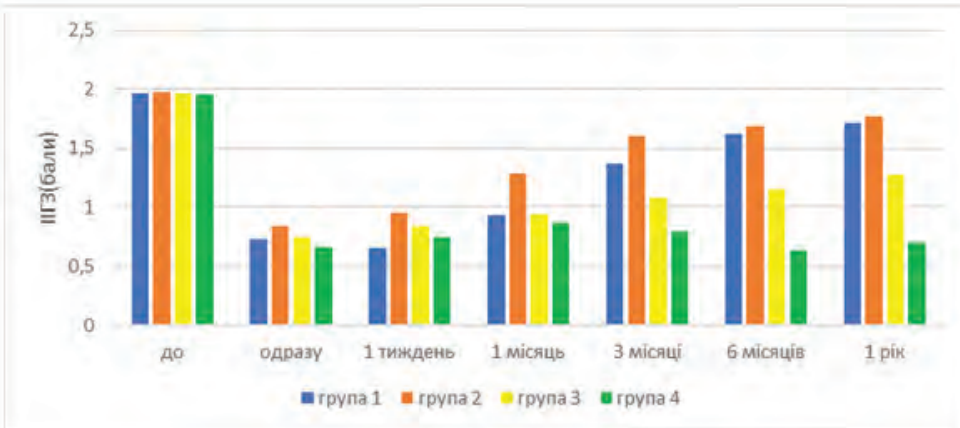

Рис. 2. Показники ІІГЗ протягом року

між усіма групами було статистично значущим $(p<0,05)$, при порівняння ІІГЗ статистичної значущості не було тільки між першою та другою групою.

Обговорення отриманих результатів. У першій групі нами було вибрано найпоширеніший спосіб лікування ГЗ. Препарати на основі фртору часто використовуються для усунення ГЗ. Механізм дії пояснюється тим, що фторид натрію вступає в реакцію з іонами кальцію і утворює кристали фториду кальцію, які закупорюють дентинні канальці, тим самим звуження дентинних канальців зменшує рух рідини. Отримані нами результати співпадають 3 багатьма дослідженнями інших авторів [1, 3, 4]. Застосування препаратів на основі фтору дає значне зниження болю при ГЗ одразу після лікування, але цей результат не є довготривалим, біль поступово повертається, хоча і не є таким за інтенсивністю, яким був до лікування.

У другій групі ми застосували настойку прополісу. Існує велика кількість досліджень, які показали високу ефективність застосування препаратів прополісу при лікування ГЗ. Механізм дії прополісу був запропонований у багатьох дослідженнях in vitro з використанням скануючої електронної мікроскопії. Хоча безперечно механізм дії прополісу потребує додаткових досліджень, але існує думка, що флавоноїди, які містяться у великій кількісті у прополісі, зв'язуються з поверхнею дентину та утворюють кристали, що заповнюють дентині канальці.
Оскільки дентинні канальці закупорені, то їх механічне закриття може перешкоджати потоку рідини. Більше того, прополіс може глибоко дифундувати всередину дентинних канальців, що може впливати на пролонгованість ефекту лікування [7, 8]. Інші дослідження показали, що прополіс стимулює вироблення трансфрормуючого фрактора росту (ТФР) -b1, що є важливим для диференціації одонтобластів. Згідно з дослідженнями, у разі прямого покриття пульпи пастою на основі прополісу частковий дентинний місток був сформований вже через чотири тижні. Це пояснюється репаративним дентиногенезом, стимульованим фрлавоноїдами прополісу, які можуть впливати на продукцію третинного дентину [11].

В третій групі нами було обрано метод лікування, як застосування діодного лазеру. За даними більшості експериментальних та клінічних досліджень, лікування ГЗ проводили за допомогою діодних лазерів з діапазоном довжин хвиль 635-830 нм. 3 одного боку, використання цих параметрів дозволяє не змінювати морфологію поверхні емалі або дентину. 3 іншого боку, частина енергії лазера при довжині хвилі 810 нм досягає пульпи та впливає на фрізіологічні функції клітини, наприклад можуть стимулюватися процеси вироблення третинного дентину. Також негайний знеболюючий ефект пояснюється пригніченням нервової передачі, що блокує деполяризацію нервових волокон пульпи $[9,10,12]$.

У четвертій групі нами був запропонований комбінований метод лікування ГЗ. На підставі усіх можливих механізмів дії настойки прополісу та низькоінтенсивного лазерного випромінювання, їх застосування було поєднано. Оптимізація лікування ГЗ комбінованим методом була направлена на отримання більш пролонгованих результатів лікування ГЗ.

Висновки. Отже, аналіз результатів запропонованої схеми лікування гіперестезії зубів у пацієнтів $з$ генералізованим пародонтитом хронічного перебігу із використанням настойки прополісу на низькоінтенсивного лазерного випромінювання говорить о високій клінічній ефективності та стійкості отриманого результату.

Перспективами подальших досліджень $€$ продовження вивчення та уточнення механізмів дії наведеного методу лікування гіперестезії зубів. 


\section{References}

1. Ivanytskyy IO, Nykolishyn AK Giperchutlyvist zubiv. Suchasni poglyady na etiologiyu, patogenez ta likuvannya [Hypersensitivity of the teeth. A modern view of etiology, pathogenesis and treatment]. Aktualni problemy suchasnoyi medytsyny. 2007; 7(20): 339-45. [Ukrainian]

2. Splieth $\mathrm{CH}$, Tachou A. Epidemiology of dentin hypersensitivity. Clin Oral Investig. 2013; 17(1): 3-8. https://doi.org/ 10.1007/ s00784-012-0889-8

3. Yarova SP, Genzytska OS, Zabolotna II. Osoblyvosti likuvannya giperesteziyi dentynu pry zakhvoryuvannyakh tkanyn parodonta [Features of the treatment of dentin hyperesthesia in periodontal tissue diseases]. Medytsyna sogodni $i$ zavtra. 2011; 3(52): 143-6. [Ukrainian]

4. Benoist L, Niang F, Faye SO, Sarr B, Seck M. Treatment of Dentin Hypersensitivity: A Systematic Review of Randomized Clinical Trials. J Dent Oral Care Med. 2016; 2(2): 204. https://doi.org/10.15744/2454

5. Khurshid, Z, Naseem, M, Zafar MS, Najeeb S, Zohaib S. Propolis: A natural biomaterial for dental and oral healthcare. $J$ Dent Res Dent Clin Dent Prospects. 2017; 11(4): 265=74. https://doi.org/10.15171/joddd.2017.046

6. Abbasi AJ, Mohammadi F, Bayat M, Gema SM, Ghadirian H, Seifi H, et al. Applications of Propolis in Dentistry: A Review. Ethiop J Health Sci. 2018; 28(4): 505-12. https://doi.org/10.4314/ejhs.v28i4.16

7. Chen CL, Parolia A, Pau A, Celerino De Moraes Porto IC. Comparative evaluation of the effectiveness of desensitizing agents in dentine tubule occlusion using scanning electron microscopy. Aust Dent J. 2015; 60(1): 65-72. doi: 10.1111/adj.12275

8. Almas K, Mahmoud A, Dahlan A. A comparative study of propolis and saline application on human dentin. A SEM study. Indian J Dent Res. 2001; 12: 21-7.

9. Kimura Y, Wilder-Smith P, Yonaga K, Matsumoto K. Treatment of dentine hyper-sensitivity by lasers: a review. $J$ Clin Periodontol. 2000; 27: 715-21.

10. Yilmaz HG, Kurtulmus-Yilmaz S, Cengiz E. Long-term effect of diode laser irradiation compared to sodium fluoride varnish in the treatment of dentine hypersensitivity in periodontal maintenance patients: A randomized controlled clinical study. Photomed Laser Surg. 2011; 29(11): 721-5. https://doi.org/10.1089/pho.2010.2974

11. Sabir A, Tabbu CR, Agustiono P, Sosroseno W. Histological analysis of rat dental pulp tissue capped with propolis. $J$ Oral Sci. 2005; 47(3): 135-8. https://doi.org/10.2334/josnusd.47.135

12. Ross G. Photobiomodulation in dentistry. Photomed Laser Surg. 2012; 30(10): 565-7. doi: 10.1089/pho.2012.9883

УДК 616.314.17-008.1-036.12-009.611-085.32-085.849.19

\section{ОТДАЛЕННЫЕ РЕЗУЛЬТАТЫ ЛЕЧЕНИЯ ГИПЕРЕСТЕЗИИ ЗУБОВ С ИСПОЛЬЗОВАНИЕМ НИЗКОИНТЕНСИВНОГО ЛАЗЕРНОГО ИЗЛУЧЕНИЯ И АПИПРОДУКТОВ \\ Демидова П. И.}

Резюме. Гиперестезия зубов часто возникает у пациентов при наличии у них заболеваний пародонта, а именно различных степеней тяжести генерализованного пародонтита. Хотя на сегодняшний день существует большое разнообразие методов лечения гиперестезии зубов, к сожалению, до сих пор необходима оптимизация существующих методов лечения ради получения пролонгированных результатов в снижении показателей гиперестезии зубов.

Целью этого исследования было оценить эффрективность лечения гиперестезии зубов у больных генерализованным пародонтитом хронического течения предложенным методом лечения с использованием низкоинтенсивного лазерного излучения и апипродуктов.

В исследовании приняло участие 104 больных с генерализованным пародонтитом хронического течения и гиперчувствительностью зубов. Пациенты были разделены на 4 группы в соответствии с полученным методом лечения. Для оценки степени выраженности гиперестезии зубов использовали индексы интенсивности и распространенности гиперестезии зубов. В первой группе для лечения гиперестезии зубов использовали лак на основе фторида натрия, во второй - настойку прополиса, в третей - низкоинтенсивное лазерное излучение (длина волны 810 нм). В четвертой группе лечение проводилось с помощью комбинированного использования настойки прополиса и низкоинтенсивного лазерного излучения (длина волны 810 нм). Значение полученных индексов интенсивности и распространенности гиперестезии зубов оценивали до лечения, сразу после лечения, через неделю, 1 месяц, 3 месяца, полгода и год после лечения в каждой группе. Статистическую достоверность результатов оценивали в IBM SPSS Statistics, V. 25.0 (Armonk, NY: IBM Corp.).

Средние значения показателей индексов интенсивности и распространенности гиперестезии зубов существенно не отличались до лечения во всех четырех группах. В каждой группе лечение было эффективным сразу после его получения, о чем свидетельствует значительное снижение средних значений индексов. Средние значения индексов интенсивности и распространенности гиперестезии зубов не 
вернулись к значениям полученных до лечения в каждой группе, однако самые низкие значения были получены в четвертой группе. Результаты сравнения между группами являются статически значимыми $(\mathrm{p}<0,05)$.

Анализ полученных результатов индексов оценки эффрективности предложенного метода лечения гиперестезии зубов свидетельствует о высокой клинической устойчивости полученного эффекта и его пролонгированном действие.

Ключевые слова: гиперестезия зубов, пародонтит, прополис, диодный лазер.

UDC 616.314.17-008.1-036.12-009.611-085.32-085.849.19

Long-Term Results of Treatment of Dentine Hypersensitivity using

Low-Level Laser Therapy and Bee Products

Demydova $P$.

Abstract. Dentine hypersensitivity often occurs in patients with conditions of periodontal disease, for example with different stages of generalized periodontitis. Although today there is a wide variety of treatments for dentine hypersensitivity, unfortunately there is still a need to optimize existing treatments in order to obtain longterm results in reducing dentine hypersensitivity.

The purpose of this study was to evaluate the effectiveness of treatment of dentine hypersensitivity in patients with generalized chronic periodontitis by the proposed method of treatment using low-level laser therapy and bee products.

Material and methods. The study included 104 patients with generalized periodontitis and dentine hypersensitivity. Patients were divided into 4 groups according to the received method of treatment. we used indices of intensity and prevalence of dentine hypersensitivity to assess the severity of dentine hypersensitivity. In the first group, varnish based on sodium fluoride was used for the treatment of dentine hypersensitivity, in the second it was ethanolic extract of propolis, in the third group we used low-level laser therapy (810 $\mathrm{nm}$ ). In the fourth group, treatment was performed using a combined usage of ethanolic extract of propolis and low-level laser therapy $(810 \mathrm{~nm})$. The values of the obtained indices of intensity and prevalence of dentine hypersensitivity were evaluated before treatment, immediately after treatment, one week, 1 month, 3 months, 6 months and one year after treatment in each group. Statistical significance of the results was evaluated in IBM SPSS Statistics, V. 25.0 (Armonk, NY: IBM Corp.).

Results and discussion. The mean values of indices of intensity and prevalence of dentine hypersensitivity did not differ significantly before treatment in all four groups. In each group, treatment was effective immediately after receiving it, as evidenced by a significant decrease in the average values of the indices. The mean values of indices of intensity and prevalence of dentine hypersensitivity did not return to the values obtained before treatment, but the lowest values were obtained in the fourth group. The results of comparisons between groups are statically significant $(p<0.05)$.

Conclusion. The analysis of the obtained results of the indices of evaluation of the effectiveness of the proposed method of treatment of dentine hypersensitivity indicates a high clinical stability of the obtained effect and its prolonged effect.

Keywords: dentine hypersensitivity, periodontitis, propolis, diode laser.

The authors of this study confirm that the research and publication of the results were not associated with any conflicts regarding commercial or financial relations, relations with organizations and/or individuals who may have been related to the study, and interrelations of coauthors of the article.

Стаття надійшла 12.05 .2020 p. Рекомендована до друку на засіданні редакційної колегії після рецензування 